\title{
Tyrphostin B50
}

National Cancer Institute

\section{Source}

National Cancer Institute. Tyrphostin B50. NCI Thesaurus. Code C1781.

A member of the tyrphostin family of tyrosine kinase inhibitors that inhibits epidermal growth factor receptor and blocks metavanadate-induced respiratory burst in alveolar macrophages. $(\mathrm{NCl})$ 